\title{
A crítica de Górgias à ontologia nas paráfrases do Tratado do Não-Ser
}

\section{Gorgias's critique of ontology in the paraphrases of the Non-Being Treaty}

\author{
CINTHIA ALMEIDA LIMA ${ }^{1}$
}

O sofista Górgias de Leontinos (485 a.C.-380 a.C.) foi um retórico e famoso orador da antiguidade. A crítica gorgiana à ontologia tem como foco principal a leitura das paráfrases do Tratado do Não-Ser na obra de Sexto Empírico e no tratado anexado à obra de Aristóteles.

As três teses que o sofista defende em seu Tratado do Não-Ser são as seguintes: "nada existe (nada é); ainda que exista é incompreensível ao homem (ainda que fosse, seria incognoscível); mesmo sendo compreensível é, todavia, impossível de se comunicar e explicar a outrem (ainda que fosse cognoscível, seria incomunicável)", pontos estes apresentados nos textos Górgias: Testemunhos e Fragmentos com tradução de Manuel Barbosa e Inês de Ornellas e Castro, Análise das Três Teses do Tratado do Não-Ser de Górgias de Leontinos do Prof. Dr. Aldo Lopes Dinucci e $O$ efeito sofístico de Barbara Cassin.

Górgias tece críticas à "noção de ser" e exalta a força da palavra para convencer, e uma vez que cada pessoa tem sua percepção individual do mundo, a linguagem pode servir de instrumento de perturbação ou de aquietação dos homens.

Duas passagens importantes devem ser aqui transcritas da referida obra da de Barbara Cassin:

DE GÓRGIAS

[1] Nada, diz ele, é: aliás, se é, é incognoscível; aliás, se é e se é cognoscível, não pode ser mostrado a outros. (2005, p. 278)

\section{ADVERSUS MATEMATHICOS}

(VII, 65-87)

(65) Górgias de Leontinos militava nas fileiras daqueles que aboliram o critério, mas ele não procedia da mesma forma que os protagóricos. Em seu escrito, Sobre o não-ser ou sobre a natureza, ele coloca em questão três preceitos que se seguem: um, o primeiro que nada é; o segundo, que mesmo se é, não pode ser apreendido pelo homem; o terceiro, que mesmo se pode ser apreendido, não pode, portanto, ser formulado e explicado a seu próximo. (Ibidem, p.283)

\footnotetext{
${ }^{1}$ Graduada em Direito, com especialização em Direito do Trabalho pela Universidade Tiradentes de Sergipe e especialização em Direito Penal e Processo Penal pela Estácio FASE. Advogada inscrita na Ordem dos Advogados do Brasil - Seccional Sergipe. Graduanda e mestranda em Filosofia, bolsista voluntária do PIBIC 2015/2016 no plano de trabalho "Os escritos teológicos do jovem Hegel" vinculado ao projeto "Idealismo alemão e cristianismo: aproximações e divergências", na Universidade Federal de Sergipe. E-mail: advcinthialima@gmail.com.
} 
Apesar do caráter histórico, e retórico, da obra O Tratado do Não-Ser, tal texto, em sua originalidade e integridade, não se perpetuou pelas alíneas do tempo, sendo encontradas apenas duas paráfrases. Estas estão dispostas na obra de Sexto Empírico e em um tratado vinculado à obra de Aristóteles.

O texto original do Tratado do Não-Ser não chegou até nós, mas sim duas paráfrases suas, uma na obra de Sexto Empírico e outra num pequeno tratado anexado à obra de Aristóteles, tratado este que sabemos hoje não ser da autoria do próprio Aristóteles. A paráfrase de Sexto aparece em sua obra Adversus Mathematicus (VII, 65 ss), a do Pseudo-Aristóteles no pequeno tratado Sobre Melisso, Xenófanes e Górgias (que chamaremos doravante de MXG). Esta última é considerada como a melhor paráfrase por ser mais completa e precisa que aquela de Sexto (DINUCCI, 2008, p. 5-6).

Por ter sido escrita sete séculos após o falecimento de Górgias, a paráfrase de Sexto apresenta algumas inconsistências que colocam a paráfrase do MXG como superior a primeira. Nas citadas paráfrases, Górgias tece críticas à noção parmenídica e melissina de ser, e busca defender a nulidade da ontologia. Em apertada síntese, Parmênides de Eléia, em seu conhecido poema, investiga os caminhos do ser e do não-ser. O ser é, e, no caso, não pode não ser. Então, "aquilo que é” é imutável e imóvel. Somente o ser é a substância permanente, e tal pensamento diferencia-se dos demais pré-socráticos, haja vista a identificação da essência (arché) com o ser. Aquilo que não tem ser não é nada, não existe (BORNHEIM, 1998, p. 53-59). Melisso de Samos teria sido um empenhado defensor do pensamento de Parmênides, com algumas particularidades. Para ele, "o um e todo é Deus; o um é eterno e ilimitado" (Ibidem, p. 66).

Para alguns comentadores de Górgias, o Tratado do Não-Ser além de ser uma crítica direcionada ao pensamento de Parmênides e Melisso (o ser como uno), também atinge diretamente qualquer ontologia positiva, bem como a concepção dos físicos que defendem o ser como múltiplo. Conforme observa Geovanni Reale,

A demonstração das três proposições (levada a efeito por uma série de dilemas cerradíssimos e em função de categorias e de uma técnica argumentativa extraída especialmente dos eleatas), longe de ser um jogo de habilidade retórica, como alguém acreditou, tem o preciso objetivo de excluir radicalmente a possibilidade de existência ou de alcançar ou, pelo menos, exprimir uma verdade objetiva. O próprio Sexto Empírico, que nos reportou uma das duas paráfrases que nos chegaram da obra, assim concluiu:

Diante de tais questões insolúveis, levantadas por Górgias, desaparece, pelo que lhe concerne, o critério da verdade: porque do inexistente, do incognoscível, do inexprimível não há possibilidade de juízo.

Por isso, se para Protágoras existia uma verdade relativa (no sentido de que tudo é verdadeiro, se assim o é para o homem), para Górgias 
não existe absolutamente verdade e tudo é falso. (2013, p. 44-45, grifo do autor).

Górgias em sua primeira tese, questiona a própria noção de ser, rebatendo ainda qualquer ideia de imutabilidade deste objeto. Na sua segunda tese, entende pela impossibilidade do homem possuir uma aptidão intelectual de apreender o hipotético ser das coisas. Já na terceira tese, acredita que a linguagem seria o último elemento com o qual seria possível a compressão única sobre todas as coisas, uma vez afastadas as hipóteses da noção de ser e cognição.

As três teses idealizadas por Górgias se opõem exatamente ao que defendia Parmênides, sendo Górgias além de "crítico de Parmênides", um "crítico do elatismo”, segundo palavras de Barbara Cassin. Para a mencionada pesquisadora,

Os sofistas - Górgias então bastante próximo de Protágoras - são um momento necessário da história da filosofia: eles refutam a abstração vazia do ser eleático pela consideração das coisas efetivas, da realidade do mundo sensível e vivo, pluralidade, movimento, subjetividade. [...] (CASSIN, 2005, p. 14).

Ainda para a aludida autora,

Todo o trabalho de Górgias consiste em tornar manifesto que o poema ontológico já é em si um discurso sofístico, e mesmo - toda a philosophia perennis está aí para testemunhar isso - o mais eficaz de todos os discursos sofísticos possíveis. Em outros termos, a sofística é uma outra espécie de poesia, poesia de gramáticos talvez, que se esforça em desvelar os mecanismos da graça eficaz da linguagem. (Ibidem, p. 18).

Assim sendo, à primeira vista, parece que a ontologia é originária de uma "confusão no uso da linguagem”, e a tese de Górgias é apagar toda a ontologia e não a construção de uma nova modalidade, como pretendeu Hegel (DINUCCI, 2013, p. $54)$.

A crítica à ontologia apresentada por Górgias foi um dos pontos investigados nesse breve escrito, a partir do pensamento que afaste uma realidade metafísica e a defesa de um ser uno, eterno, não-gerado e imutável.

Hoje a ontologia conserva algum sucesso, mas o pior que ainda faz é se passar pela disciplina eminentemente filosófica, o que coincide com a ruína da filosofia. A ontologia deve ser atacada, primeiro, porque é um erro, como bastou para Górgias, depois porque é um erro bem sucedido e, por isso, nefasto. Se depender dela e onde ela tiver influência, a ciência e a sabedoria serão impedidas. Por isso, talvez hoje haja mais razão para ouvir Górgias do que em seu próprio tempo. (DINUCCI; CABECEIRAS, 2013, p. 52).

A linguagem tem grande importância para a filosofia e o discurso pode ser uma "arma" poderosa em favor do homem, tanto para sua própria glória como para a 
destruição de seus oponentes, incitando assim sentimentos bons e ruins, a exemplo da empatia e do medo, do amor e do ódio, da serenidade e da perturbação etc.

Destarte, a propagação da palavra, ainda que inserida em um contexto cultural e semântico, não carrega em si a representação fiel do objeto a que se refere, sendo, portanto, suscetível a deturpações do emissor e do receptor no que tange ao entendimento.

\section{Referências}

BARBOSA, M; CASTRO, I. O. Górgias: Testemunhos e Fragmentos. Lisboa: Colibri, 1993.

CASSIN, B. O efeito sofístico. Trad. de Ana Lúcia de Oliveira, Maria Cristina Franco Ferraz e Paulo Pinheiro. Coleção TRANS. Editora 34. 2005.

DINUCCI, A. Análise das Três Teses do Tratado do Não-Ser de Górgias de Leontinos. O que nos faz pensar, no 24, p. 05-22, outubro de 2008.

. A Paráfrase do MXG do Tratado do Não-Ser de Górgias de Leontinos. IN:

Trans/Form/Ação, v. 31, p. 197-203, 2008.

DINUCCI, A; CABECEIRAS, A. Górgias e a destruição da ontologia. Conhecimento e Linguagem, org. Sergio Hugo Menna. Porto Alegre: Redes Editora, p. 49-56, 2013.

REALE, G. História da filosofia grega e romana: Sofistas, Sócrates e socráticos menores. Trad. de Marcelo Perine. Vol. II. São Paulo: Edições Loyola, 2013.

Submissão: 02. 11. 2017 / Aceite: 04. 03. 2018. 